\title{
PHYSIOLOGICAL EFFECTS OF DIATOMACEOUS EARTH ON MENTHA VIRIDIS PLANTS GROWN UNDER DROUGHT CONDITIONS
}

Hanan M.H. Ali; Nadia A.M. El-Said and Soad M.M. Salem

Medicinal and Aromatic Plants Res. Dept., Hort. Res. Inst., ARC, Giza, Egypt.

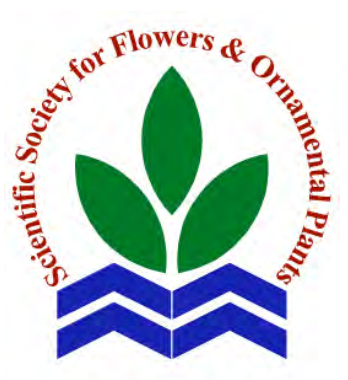

Scientific J. Flowers \& Ornamental Plants, 1(2):101-115 (2014).

Received:

20/7/2014

Revised by: Prof. Dr. M.S. Hanafy, Cairo Univ.

Prof. Dr. Shadia K. Ahmed, Hort. Res. Inst., ARC.

ABSTRACT: This study was carried out during 2012 and 2013 seasons at the experimental farm of Medicinal and Aromatic Plants Research Department in El-Kanater El-Khairia. The investigation aimed to study the effect of irrigation at 25, 50 and 100\% from field capacity (FC) combined with diatomaceous earth (DDM) at 0, 2 and 4 $\mathrm{g} / 10 \mathrm{~kg}$ soil in order to regulate water irrigation and to study their effect on vegetative growth and volatile oil production of spearmint plants (Mentha viridis L.). The obtained results are summarized as follows: in all cuts in the two seasons, the plants received DDM at 4 g/10 kg soil $+100 \%$ FC, showed stimulation in growth characters, i.e plant height, branching, fresh and dry weights of spearmint plants. Although the highest volatile oil percentage/plant through the two seasons was achieved when the plants were treated with 25\% and 50\% FC but the volatile oil yield was the highest at $4 \mathrm{~g}$ DDM $/ 10 \mathrm{~kg}$ soil + $100 \%$ FC. The highest percentage of Carvone (the main component of the volatile oil) was produced with $4 \mathrm{~g}$ DDM $/ 10 \mathrm{~kg}$ soil $+100 \%$ FC. Proline content was decreased with increasing irrigation and diatomaceous earth rate, this refers to response of mint plants to treated by diatomaceous earth with the irrigation at $50 \%$ or $100 \%$ FC and not exposed to stress at 25\% FC compared to the control (the highest proline content).

Key words: Mentha viridis, silicon, irrigation, diatomaceous earth, field capacity.

\section{INTRODUCTION}

Medicinal and aromatic plants have a major role in agriculture and industry. They are the main source of safety drugs and row substances used in manufacturing of pharmaceuticals.

Spearmint (Mentha viridis L), belongs to family Lamiaceae (Labiatae), its leaves and essential oil are used as carminative, antimicrobial and anti-inflammatory (Poiata et al., 2006), as antioxidant, popular flavoring and beverage (Bichra et al., 2013).

Water is a fundamentally important component for metabolism of all living organisms, facilitating many vital biological reactions by being a solvent, a transport medium, an evaporative coolant and providing the energy necessary to drive photosystem reaction center through water autolysis (Mundree et al., 2002).

Water stress usually causes a decrease in plant growth criteria and crop production. It causes changes of chlorophyll component contents and damage of photosynthesis apparatus. It also inhibits the photo-chemical activities of calvin cycle enzymes. Faraz Ahmed et al. (2007) on Triticumae stivum L. and Abdalla and El-khoshiban (2007) reported that water stress increased the growth of roots but decreased those of shoots, number of leaves, fresh and dry weights of shoots and roots. Also, several workers showed that water stress reduced the amounts of auxins, gibberellins and 
cytokinins, while it reversibly raised ABA and secondary metabolites (Nan et al., 2002).

Diatomites (DDM) are naturally occurring sedimentary rock primarily composed of fossilized remains of fresh water diatoms. It is chemically composed of $\mathrm{SiO}_{2}(86-89 \%)$ in a soluble form available to plant and small amount of trace elements. It is considered as long-lasting recyclable, reusable (do not breaking or decompose like other growing mediums and thus economic) and environmentally friendly soil fertilizer and enhancer. Its beneficial effect was emphasized by (kruger, 2006, Jessen, 2007 and Abdalla, 2009) as follows:

1. Improve the physical structure of soil by breaking up heavy based soil and retaining moisture in light or sandy soil for longer period (hold up to $200 \%$ of its weight in water) without interfering with soil chemistry.

2. It minimizes leaching and run off water and nutrients thus reducing watering significantly.

3. Insulates, aerates, promotes capillary action and slowly release soluble silica to the plants as required due to its high absorbency and lateral water movement ability.

4. It enables oxygen to penetrate the plant roots zone without any difficulty acquire self resistance against abiotic stresses.

5. Moreover, diatomite is used as natural physically insecticide. Recently, numerous studies have demonstrated that silicon is one of the important elements for the plants and plays an important role in tolerance of plants to environmental, stress heavy metal and biotic stress (Gong et al., 2005 and Tahir et al., 2006).

With respect to water stress, relevant work is limited. Silicon (DDM contain 86$89 \%$ of $\mathrm{SiO}_{2}$ ) is known to increase drought tolerance in plants by maintaining plant water balance and photosynthetic activity
(Hattor et al., 2005). Faraz Ahmed et al. (2007) reported that increased levels of Si (50-150 g/kg soil) significantly increased plant biomass, plant weights and dry matter production under water stress $(50 \%)$ of field capacity. Si fertilization increases crop yield and quality and thus insures high production under severe biotic and abiotic stresses (Hou et al., 2006).

The present investigation was conducted to study the effect of irrigation treatments combined with DDM on growth, yield and essential oil production of Mentha viridis plants.

\section{MATERIALS AND METHODS}

This study was carried out at the experimental farm of Medicinal and Aromatic Plants Research Department in ElKanater El-Khairia, Egypt in the two seasons of 2012 and 2013.

\section{1- Experimental procedures:}

Spearmint seedlings (12-15 cm in height, with 10-12 leaves) were obtained from ElKanater El-Khairia, experimental farm of Medicinal and Aromatic Plants Research Department and transplanted in plastic pots (30 cm diameter each pot was contained 15kg soil) on $15^{\text {th }}$ February, 2012 and 2013. Chemical fertilizers (NPK) were added at the recommended level in five doses, the $1^{\text {st }}$ one was for all phosphorous amount which was added during soil preparation, the rest (NK) were applied in two equal doses for each cut, on March, 30 and April, 30 for the $1^{\text {st }}$ cut and May, 18 (after the $1^{\text {st }}$ cut) and June, 20 for the $2^{\text {nd }}$ one in the two seasons. Physical and chemical analysis are shown in Table (a).

\section{2- Treatments:}

a. Irrigation was done at 25, 50 and $100 \%$ of field capacity (FC).

b. Diatomite (DDM) is a natural diatomaceous earth originated from fossilized remains of fresh water cell wall impregnated with silica. Its $\mathrm{pH}$ is neutral and it contains some elements as shown in Table (b). 
Table a. Physical and chemical analysis of the soil used for growing Spearmint (Mentha viridis L.) plants, before treatments.

\begin{tabular}{|c|c|c|c|c|c|c|}
\hline \multicolumn{7}{|c|}{$\begin{array}{l}\text { Physical analysis } \\
\end{array}$} \\
\hline & Clay (\%) & & Silt (\%) & & Sand (\%) & Texture grade \\
\hline & 18.5 & & 26.3 & & 55.2 & Sandy loam \\
\hline \multicolumn{7}{|c|}{ Chemical analysis } \\
\hline & $\begin{array}{l}\text { Total nut } \\
\text { Content } \\
\end{array}$ & & \multirow[t]{2}{*}{ pH } & \multirow{2}{*}{ 巧 } & Soluble cations (meq/l) & $\begin{array}{l}\text { Soluble anions } \\
(\mathrm{meq} / \mathrm{l})\end{array}$ \\
\hline $\mathbf{N}$ & $\mathbf{P}$ & $\mathbf{K}$ & & & $\mathrm{Ca}^{++} \quad \mathrm{Mg}^{++}$ & $\mathrm{HCO}_{3}^{--} \mathrm{Cl}^{-} \quad \mathrm{SO}_{4}^{--}$ \\
\hline 24.30 & 208.00 & 340.70 & 7.5 & 4.45 & $\begin{array}{llll}12.70 & 6.76 & 18.76 & 14.40 \\
\end{array}$ & $2.00 \quad 17.14 \quad 33.48$ \\
\hline
\end{tabular}

Table b. Major elements in diatomaceous earth according to Abdalla (2011).

\begin{tabular}{cc}
\hline Major elements & \% \\
\hline $\mathrm{SiO}_{2}$ & 89.00 \\
$\mathrm{Al}_{2} \mathrm{O}_{3}$ & 5.95 \\
$\mathrm{Fe}_{2} \mathrm{O}_{3}$ & 0.88 \\
$\mathrm{CaO}$ & 0.10 \\
$\mathrm{~K}_{2} \mathrm{O}$ & 0.63 \\
$\mathrm{MgO}$ & 0.20 \\
$\mathrm{Na}_{2} \mathrm{O}$ & 0.32 \\
$\mathrm{TiO}_{2}$ & 0.29 \\
$\mathrm{H}_{2} \mathrm{O}$ & 3.00 \\
\hline
\end{tabular}

Diatomite (DDM) was added to pots at the rates of $0,1,2$ and $4 \mathrm{~g} / 10 \mathrm{Kg}$ soil. The application of diatomite was divided into four doses, the first and the second doses was after 30 and 45 days from transplanting. The third one was applied after the first cut and the fourth after 15 days from the third doses.

The plants were harvested twice, the first cut was on $15^{\text {th }}$ May, and the second one on $15^{\text {th }}$ July in both seasons.

\section{3- Experiment layout:}

The experiment layout was designed in split plots, with 12 treatments, (each treatment was replicated 3 times and each replicate consisted of 10 pots (1 plant/pot)).

Irrigation treatments occupied the main plots, while diatomite treatments were arranged in subplots. The statistical analysis was conducted according to Snedecor and Cochran (1980).

\section{4- Data recorded:}

The following data were recorded

1. Plant height $(\mathrm{cm})$ and number of branches/plant.
2. Herb fresh and dry weights (g/plant) of aerial parts.

3. Volatile oil percentage was determined in dry herb according to the British Pharmacopeia (1963).

4. Volatile oil yield (ml/plant) $=$ herb dry weight per plant $\times$ oil $\%$ in dry herb.

5. GLC analysis of essential oil: volatile oil samples were taken from the oil obtained in the second cut of the second season and were analyzed using gas liquid chromatography (GLC), to determine their constituents according to the methods described by Bunzen et al. (1969) and Hoftman (1967).

6. Proline content in dry leaves was determined according to Bates et al. (1973).

\section{RESULTS AND DISSCUTION}

1- Plant height and number of branches/plant:

Data in Table (1) indicated that, irrigation treatments and diatomaceous earth had a significant effect on both plant height and number of branches/plant in both seasons.

It could be noticed that the tallest plants in the first and second seasons at the two cuts were recorded when the plants were irrigated at $100 \%$ of the field capacity (FC) giving 43.03 and $39.04 \mathrm{~cm}$ at first and second cuts in the first season, respectively. The same trend was observed in the second 
Hanan M.H. Ali et al.

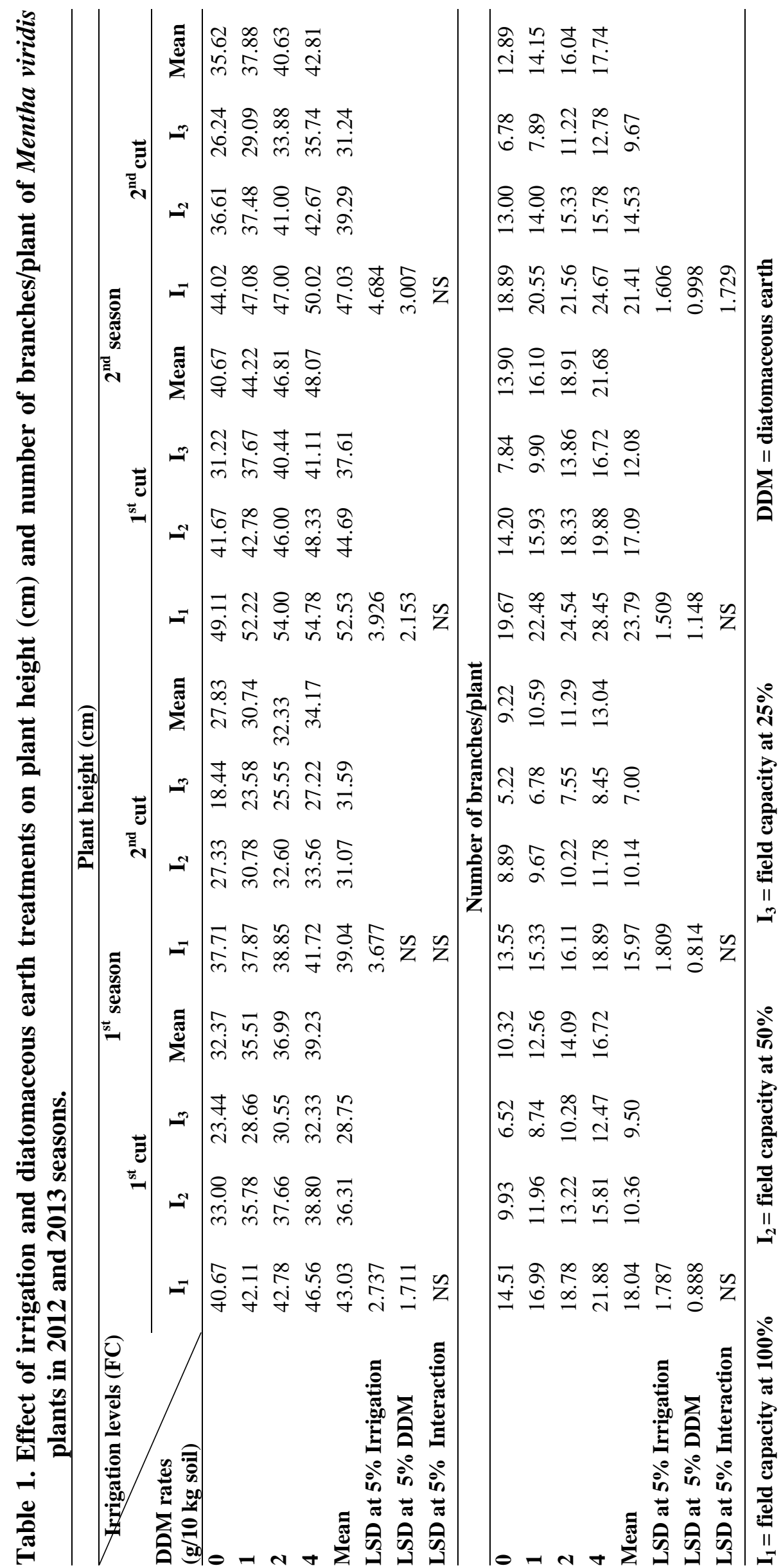


season giving 52.53 and $47.03 \mathrm{~cm}$. The shortest plants at the two cuts of the two seasons were those plants irrigated with $25 \%$ FC.

The addition of diatomaceous earth (DDM) had a significant effect on the plant height of spearmint plants in the first season except for the second cut, i.e. mint plants showed no significant effect on plant height due to (DDM) at the second cut only. Tallest plants were those received (DDM) at 4 g/10kg soil giving 39.23 and $34.17 \mathrm{~cm}$ at the first and the second cuts, respectively. In the second season the recorded data were 48.07 and $42.81 \mathrm{~cm}$ at first and second cuts, respectively. The shortest plants were untreated plants giving 32.37 and $27.83 \mathrm{~cm}$ in the first season, while in the second season the values were 40.67 and $35.62 \mathrm{~cm}$ at the first and second cuts, respectively.

Regarding the interaction between the irrigation and diatomite treatments on plant height, it was clear from data in Table (1) that there were insignificant differences on plant height at the two cuts in both seasons.

The same trend was observed in number of branches, the greatest number of branches was recorded when the plants were irrigated at $100 \%$ FC giving 18.04 and 15.97 branches/plant in the first and second cuts of the first season, respectively. Also in the second season, the recorded values were 23.79 and 21.41 branches/plant at the first and second cuts, respectively.

Concerning the effect of diatomaceous earth (DDM) on number of branches, results presented in Table (1) showed that, the highest values of the first season were obtained when spearmint plants were treated with (DDM) at $4 \mathrm{~g} / 10 \mathrm{~kg}$ soil giving 16.72 and 13.04 branches/plant at the first and second cuts and 21.68 and 17.74 in the second season at first and second cuts, respectively. The lowest values 10.32 and 9.22 branches/plant were obtained from untreated plants in the first season at first and second cuts. In the second season the values were 13.90 and 12.89 branches/plant at first and second cuts, respectively. These results are in accordance with those reported by Abbaszadeh et al. (2008) on mint. These results may be due to diatomaceous earth (DDM), being mostly chemically composed of $\mathrm{SiO}_{2}$ (82-89\%), it is considered as a fertilizer and multifunctional purposes as well as beneficial effects in both soil and plants (Kruger, 2006). Si has been generally recognized to have a beneficial role in stimulating the various forms of growth and the biochemical contents of many plant species (Matichenkov and Kosobrukhov, 2004 and Hull, 2004).

Concerning the effect of interactions on number of branches/plant the results showed insignificant differences in the first season at the two cuts and in the second season at the first cut. The highest number of branches/plant was recorded in the second season at the second cut when the plants were irrigated at $100 \%$ FC and applied with $\mathrm{DDM}$ at $4 \mathrm{~g} / 10 \mathrm{Kg}$ soil, while the lowest value (6.78 branches/plant) was produced with the second cut in the second season, was recorded when the plants were irrigated at 25\% FC and untreated DDM. These results are in harmony with the results obtained by Savant and Sawant (1995) and Liang et al. (2007).

\section{2- Herb fresh and dry weights of aerial parts:}

Data in Table (2) indicated that increasing the rates of irrigation from $25 \%$, $50 \%$ up to $100 \%$ FC resulted in significant increases in fresh and dry weights of aerial parts in both cuts in the two seasons. The highest fresh and dry weights/plant were recorded when spearmint plants were irrigated at $100 \%$ FC. These results are in agreement with Abdalla (2011) on Lupinus albus.

As for the effect of diatomaceous earth on the fresh and dry weights of spearmint plants, it is clear that the highest rate of diatomaceous earth (DDM) $4 \mathrm{~g} / 10 \mathrm{~kg}$ soil was the most effective treatment in this concern which gave $32.00 \mathrm{~g}$ and $28.11 \mathrm{~g}$ fresh herb and 21.07 and $12.10 \mathrm{~g}$ dry herb/plant 


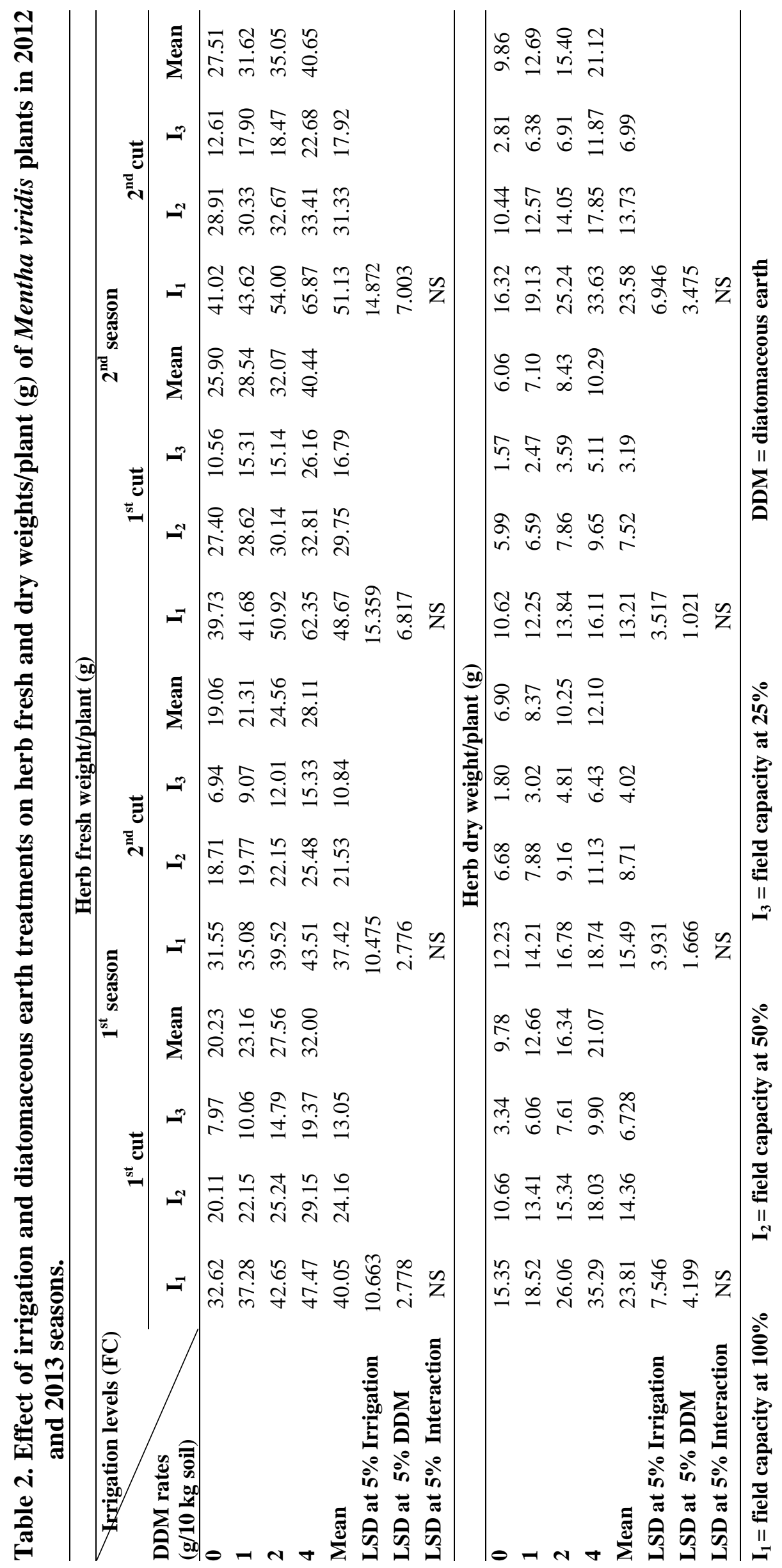


in the first season in the two cuts, respectively. The same trend was observed in the second season for the two cuts. The highest values were 40.44 and $40.65 \mathrm{~g}$ fresh herb/plant and 10.29 and $21.12 \mathrm{~g}$ dry herb/plant, respectively. These results are in harmony with Galvez et al. (1987), Savant and Sawant (1995) and Liang et al. (2007) on rice plants.

Also data in Table (2) showed that, interaction treatments gave mostly the highest fresh and dry weights of mint plants; the treatment of $(100 \% \mathrm{FC}+4 \mathrm{~g} / 10 \mathrm{~kg}$ soil $)$ produced the maximum fresh and dry herb in the two cuts and in the two seasons. Plants of these treatments produced 47.47 and $43.51 \mathrm{~g}$ fresh herb/plant at the first and second cuts in the first season while in the second season produced 62.35 and $65.87 \mathrm{~g}$, respectively. Herb dry weight/plant values were 35.29 and $18.74 \mathrm{~g}$ dry herb/plant for the first and second cuts in the first season and 16.11 and 33.63 g dry herb/plant in the second season at the first and second cuts. However, the differences between the treatments were insignificant.

It is of worthy to emphasize that, a stimulation effect in spearmint growth was observed due to irrigation treatments interacted with DDM application these findings were found to be in harmony with (Savant et al., 1997, Matichenkov and Kosobrukhov, 2004 and Abdalla, 2010) they reported that the increment in herb weight may be due to $\mathrm{Si}$ application to various tested plants which increased the photosynthetic rates through increasing both the photochemical efficiency, the stomata conductance and the net assimilation rate of $\mathrm{CO}_{2}$, therefore improved the supply and the content of carbohydrates in treated plants (Matichenkov and Calvert, 2002). It was noticed that these highest values of fresh and dry herb of mint plant were found to be higher by about $40-50 \%$ than the values of control plant under all irrigation treatments.

\section{3- Volatile oil percentage:}

Data presented in Table (3) showed the effect of irrigation FC, diatomaceous earth
(DDM) and the interaction between them on volatile oil of spearmint plants.

Increasing the rates of irrigation (FC) from $25 \%$ up to $100 \%$ resulted in significant decreases in volatile oil percentage in both cuts in the two seasons. The highest values were recorded when spearmint plants were irrigated at 25\% FC. Data in Table (3) clearly emphasized that, irrigation gave the main effect on oil production of spearmint plants compared to DDM. Essential oil content (\%) showed a decreasing tendency with increasing water field capacity. So, the highest values in this concern were accompanied with irrigation at 25\% FC in the two cuts of the two seasons. These results are in accordance to Afify et al. (1993) and Abou Dahab et al. (2010). These results may be explained through the findings of Penka (1978) and Farahani et al. (2009), they mentioned that drought stress increases the essential oil percentage of more medicinal and aromatic plants, because in case of stress, more metabolites are produced in the plants and some substances prevent oxidization in the cells.

As for DDM application no obvious effect was detected on volatile oil production of spearmint plants. However, in the first season, it was observed that the application of DDM to spearmint plants at all concentrations varied significantly in volatile oil percentage in comparison with control plants in both cuts. The same trend was mostly observed in the second season for the two cuts. In other words, it could be noticed that volatile oil percentage may be affected by DDM application regardless its concentration. These results are in harmony with Aliabadi et al. (2009) on balm.

As for the effect of the interaction between irrigation and diatomaceous earth, the results showed a significant difference in volatile oil percentage in the first cut in the first season. In the second season the interaction had no significant effect on volatile oil percentage compared with control in both cuts. The highest volatile oil percentage was found mostly in 25\% FC interacted with 
Hanan M.H. Ali et al.

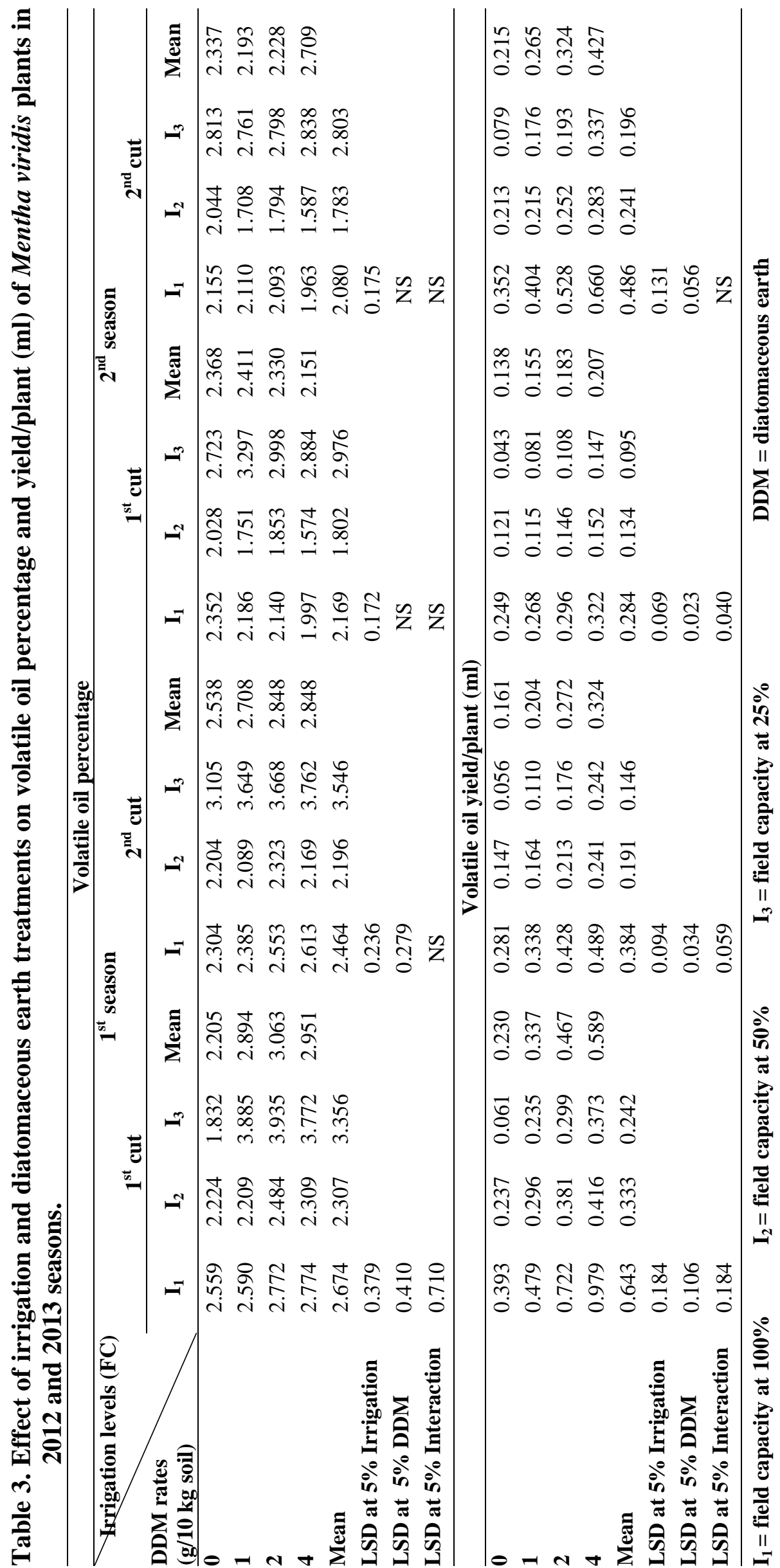


DDM at all concentration compared with the rest of the treatments. This result may be in accordance with the previous results of DDM and irrigation each of them alone. These results are in agreement with Abou-Dahab et al. (2010) on Majorana hortensis.

\section{4- Volatile oil yield/plant:}

Data in Table (3) showed that irrigation had a significant effect on oil yield/plant in the two cuts of the first and second seasons. Increasing irrigation from 25\% FC up to 100\% FC increased volatile oil yield/plant. The highest values were recorded when spearmint plants were irrigated at $100 \%$ FC. The values were 0.643 and $0.384 \mathrm{ml} /$ plant in the first and the second cuts, respectively in the first season. The same trend was observed in the second season; the highest values $(0.284$ and $0.486 \mathrm{ml} /$ plant $)$ were obtained in case of $100 \%$ FC in the first and second cuts, respectively.

As for the effect of diatomaceous earth (DDM) on essential oil yield, it is clear that all treatments had mostly significant effect. Increasing DDM rate from 1 up to $4 \mathrm{~g} / 10 \mathrm{~kg}$ soil significantly increased oil yield/plant in both seasons at the two cuts. The highest values ( 0.589 and $0.324 \mathrm{ml} /$ plant) in the first season and (0.207 and $0.427 \mathrm{ml} /$ plant) in the second season respectively, were recorded when the plants were treated with DDM at $4 \mathrm{~g} / 10 \mathrm{~kg}$ soil.

Data in Table (3) pointed out that volatile oil yield of spearmint plant showed an increase in response to interaction treatments in comparison with control. This increase was accompanied with increasing irrigation and DDM rates. The highest values in this concern were 0.979 and $0.489 \mathrm{ml} /$ plant at the first and second cuts in the first season, respectively. While in the second cut at the second season the interaction had no significant effect.

The increment in volatile oil yield/plant may be due to diatomaceous earth (DDM) which reduced transpiration and increased water leaf content which reflects in increasing photosynthesis. These results are in accordance with Abdalla (2011) on Lupinus albus plant.

\section{5- GLC analysis of essential oil:}

The GLC analysis were carried out on the essential oil of Mentha viridis plants of 4 treatments in the second cut of second season,100\% FC + 0 DDM, 100\% FC + DDM at $4 \mathrm{~g} / 10 \mathrm{~kg}$ soil, $50 \% \mathrm{FC}+\mathrm{DDM}$ at 4 $\mathrm{g} / 10 \mathrm{~kg}$ soil and $25 \% \mathrm{FC}+\mathrm{DDM}$ at $4 \mathrm{~g} / 10$ $\mathrm{kg}$ soil. The data were recorded in Table (4) and Figures (1-4) revealed that, Carvone and $\mathrm{D}$-Limonene were the main components.

The major constituents of the essential oil were influenced under all irrigation regimes. It was observed that Carvone content tended to increase up to $62.63 \%$ in case of $100 \%$ FC with DDM at $4 \mathrm{~g} / 10 \mathrm{~kg}$ soil. Also data emphasized that D-Limonene content tended to increase up to $27.03 \%$ under $50 \%$ FC with DDM at $4 \mathrm{~g} / 10 \mathrm{~kg}$ soil.

\section{6- Proline contents:}

The results in Table (5) revealed that proline content was affected by irrigation levels. The lowest concentration of proline was found in the spearmint plants irrigated with $100 \%$ FC, followed by $50 \%$ FC when compared with those irrigated at $25 \%$ FC. Numerous studies have shown that the proline content in higher plants increases under different environmental stresses (Laszlo and Arnould, 2009).

As for DDM, it can be noticed that the treatment without DDM (DDM at $0 \mathrm{~g} / 10 \mathrm{~kg}$ soil) produced the highest proline value compared with DDM at 1,2 or $4 \mathrm{~g} / 10 \mathrm{~kg}$ soil.

The interaction between irrigation (I) and DDM significantly decreased proline content. The lowest value was $373.520 \mu \mathrm{g} / \mathrm{g}$ dry leaves when the plants treated with DDM at $4 \mathrm{~g} / 10 \mathrm{~kg}$ soil and irrigated at $100 \%$ FC. Silicon increased the protein content of drought stressed plants by increasing protein biosynthesis or decreasing its oxidation which is accomplished by an increase in the activities of certain antioxidant and hydrolytic enzymes as peroxidases (POD), catalases (CAT), esterases (EST) and acid phosphatases (ACP) (Zhu et al., 2004 and Gong et al., 2005). 
Hanan M.H. Ali et al.

Table 4. Effect of irrigation and diatomaceous earth treatments on volatile oil components $\%$ of Mentha viridis plants in the $2^{\text {nd }}$ Season $\left(2^{\text {nd }}\right.$ cut $)$.

\begin{tabular}{|c|c|c|c|c|}
\hline Treatments & $\mathrm{I}_{1}+0 \mathrm{DDM}$ & $\begin{array}{c}I_{1}+\text { DDM at } \\
4 \mathrm{~g} / 10 \mathrm{~kg} \text { soil }\end{array}$ & $\begin{array}{c}I_{2}+\text { DDM at } \\
4 \mathrm{~g} / 10 \mathrm{~kg} \text { soil }\end{array}$ & $\begin{array}{l}I_{3}+\text { DDM at } \\
4 \mathrm{~g} / 10 \mathrm{~kg} \text { soil }\end{array}$ \\
\hline$\alpha$-Pinene & 0.98 & 0.85 & 0.88 & 0.86 \\
\hline$\beta$-Pinene & 3.25 & 1.26 & 1.25 & 1.33 \\
\hline D-Limonene & 24.62 & 25.37 & 27.03 & 24.79 \\
\hline$\rho$-Cymene & 1.06 & 0.58 & 0.73 & 0.84 \\
\hline 1,8- Cineole & 0.99 & 0.63 & 0.80 & 0.53 \\
\hline$\gamma$-Terpinone & 3.64 & 3.07 & 1.88 & 2.63 \\
\hline Carvone & 61.58 & 62.63 & 60.29 & 61.17 \\
\hline$\alpha$-Terpinone & 0.38 & 0.34 & 0.36 & 0.28 \\
\hline$\beta$-Caryophyllene & 0.71 & 0.92 & 0.45 & 0.43 \\
\hline Eugenol & 1.03 & 0.53 & 1.08 & 1.31 \\
\hline
\end{tabular}

$I_{1}=$ field capacity at $100 \% \quad I_{2}=$ field capacity at $50 \%$

$I_{3}=$ field capacity at $25 \% \quad$ DDM $=$ diatomaceous earth

Table 5. Effect of irrigation and diatomaceous earth treatments on proline content $\mu \mathrm{g} / \mathrm{g}$ dry leaves of Mentha viridis plants in the $2^{\text {nd }}$ Season $\left(2^{\text {nd }}\right.$ cut $)$.

\begin{tabular}{|c|c|c|c|c|}
\hline $\begin{array}{l}\text { Irrigation levels (FC } \\
\text { (g/10 kg soil) }\end{array}$ & $\mathbf{I}_{1}$ & $\mathbf{I}_{2}$ & $\mathbf{I}_{3}$ & Mean \\
\hline $\mathbf{0}$ & 632.140 & 710.330 & 1663. 670 & 1002.053 \\
\hline 1 & 566.110 & 602.620 & 1066.130 & 744.953 \\
\hline 2 & 431.890 & 538.860 & 996.500 & 655.750 \\
\hline 4 & 373.520 & 430.990 & 824.940 & 543.150 \\
\hline Mean & 500.915 & 570.700 & 1137.810 & \\
\hline LSD at $5 \%$ Irrigation & 52.364 & & & \\
\hline LSD at $5 \%$ DDM & 68.666 & & & \\
\hline LSD at $5 \%$ Interaction & 263.64 & & & \\
\hline
\end{tabular}

$I_{1}=$ field capacity at $\mathbf{1 0 0} \%$

$I_{2}=$ field capacity at $50 \%$

$I_{3}=$ field capacity at $25 \%$

DDM = diatomaceous earth 


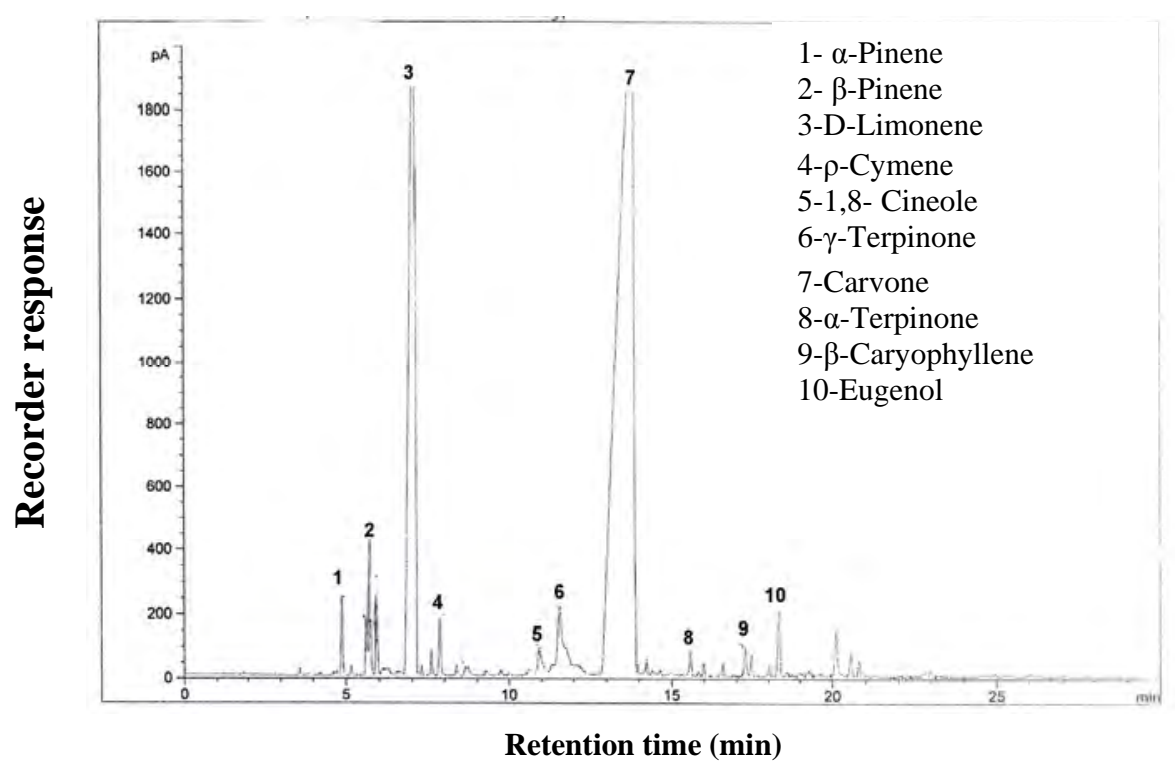

Fig. 1. Chromatogram of mint volatile oil under 100\% FC + 0 DDM

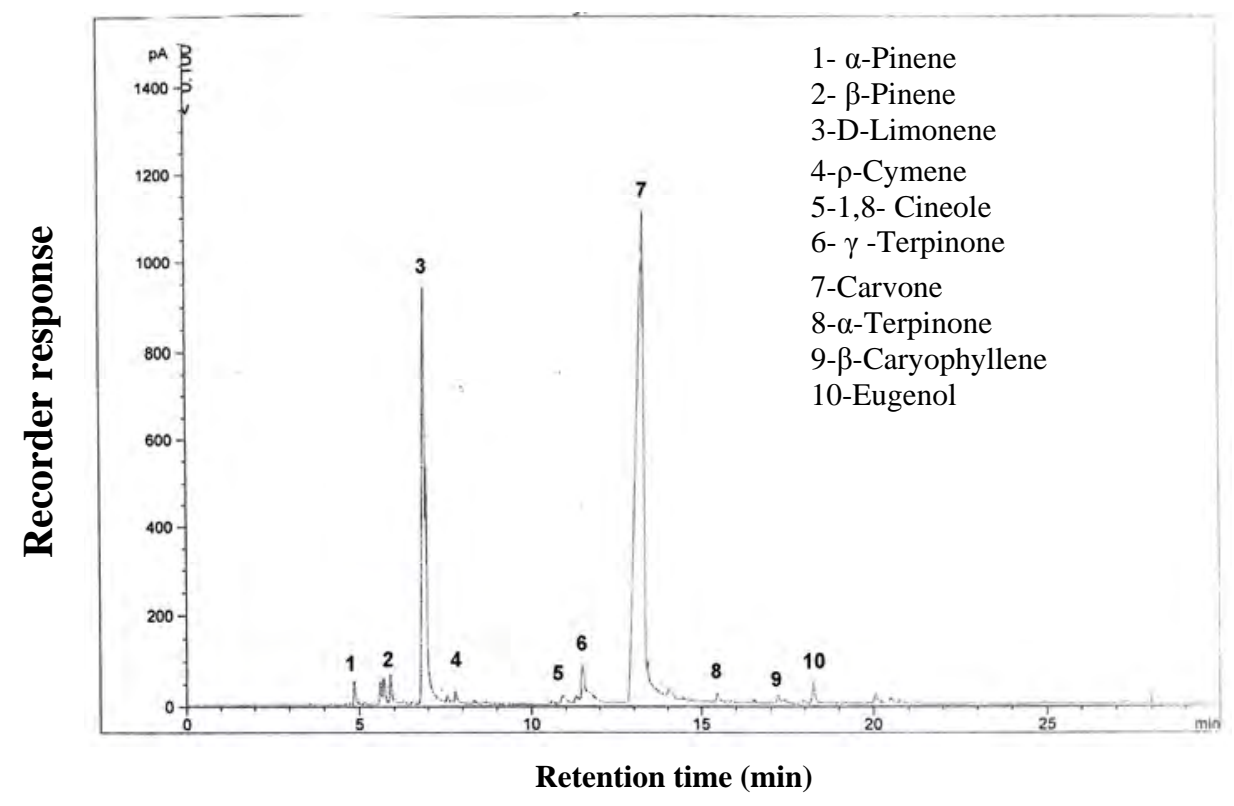

Fig. 2. Chromatogram of mint volatile oil under 100\% FC + DDM at $4 \mathrm{~g} / 10 \mathrm{~kg}$ soil 
Hanan M.H. Ali et al.

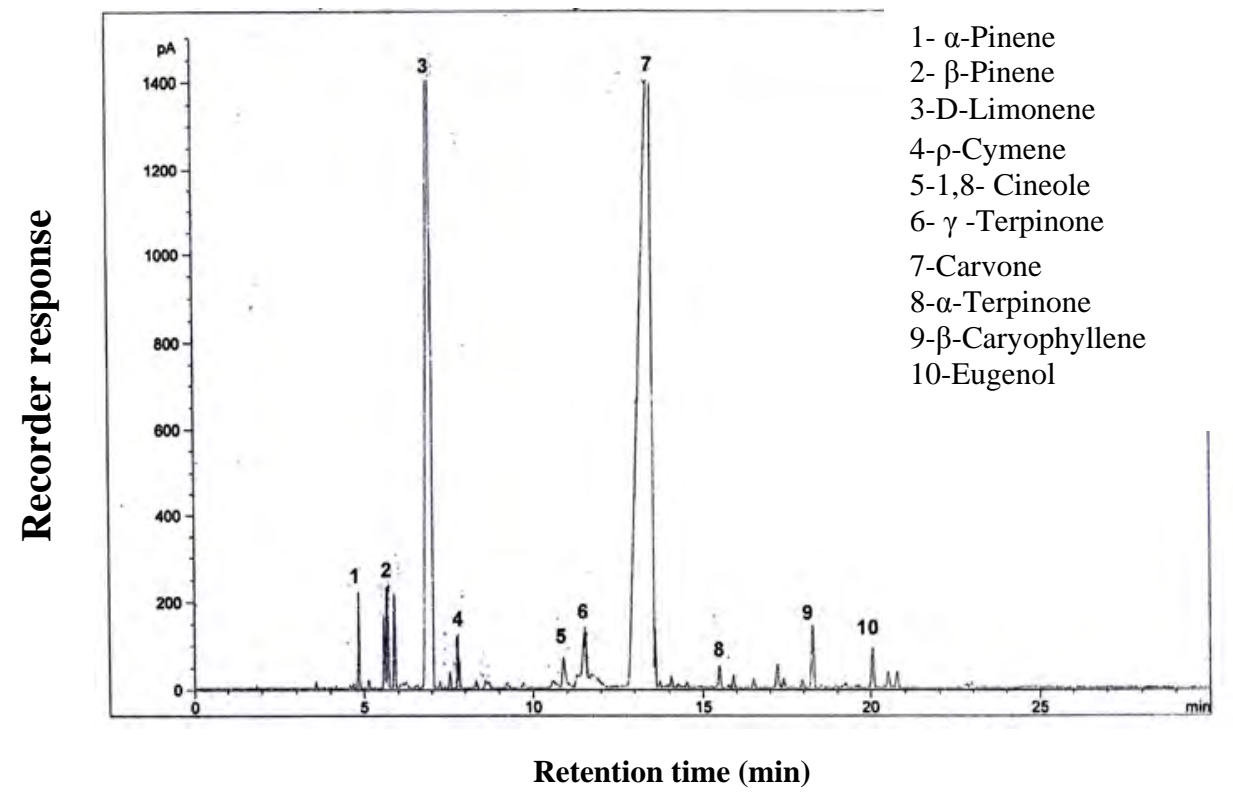

Fig. 3. Chromatogram of mint volatile oil under 50\% FC + DDM at $4 \mathrm{~g} / 10 \mathrm{~kg}$ soil

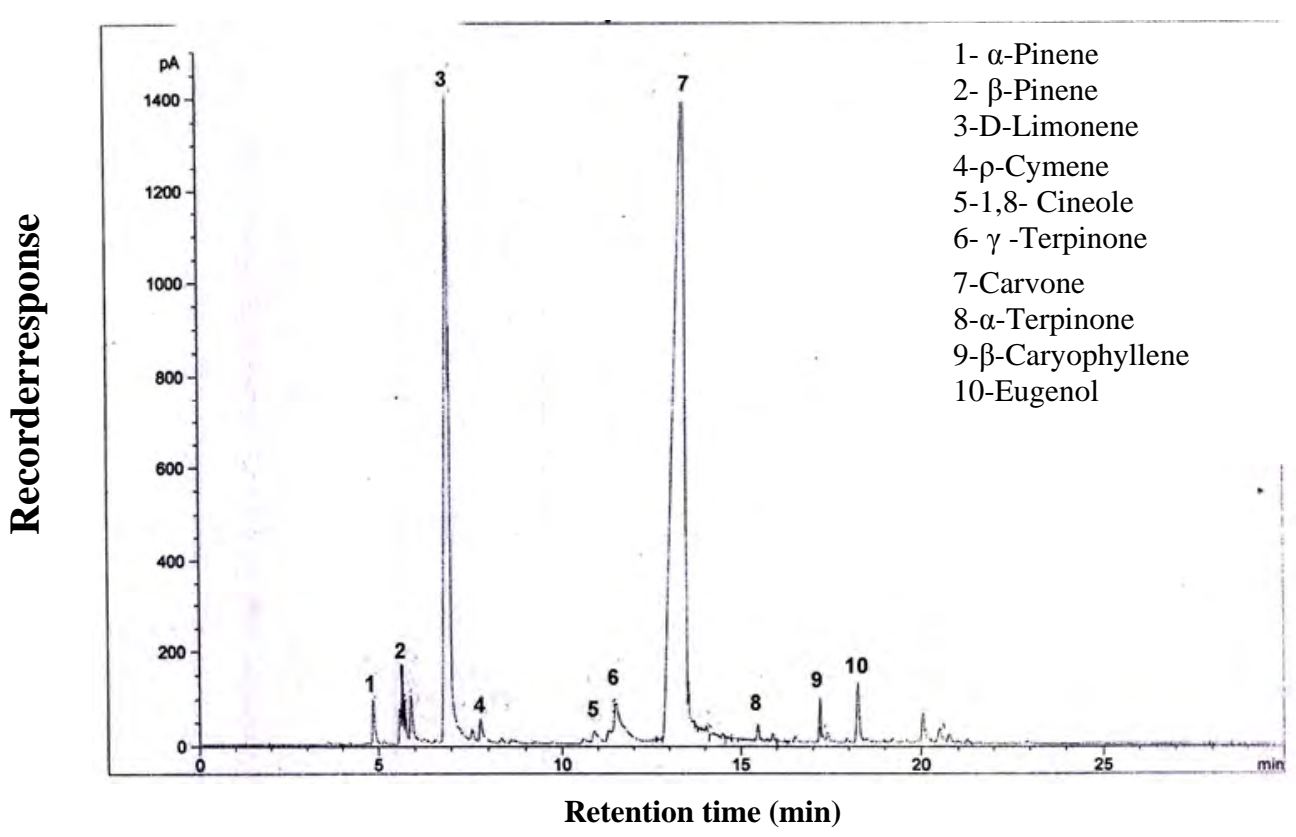

Fig. 4. Chromatogram of mint volatile oil under $25 \%$ FC + DDM at $4 \mathrm{~g} / 10 \mathrm{~kg}$ soil 
From these results, it could be concluded that, mint plants were stressed under irrigation with 25\% FC. So proline content was higher than those plants irrigated with (50\% and 100\% FC).

Also, DDM at all concentration used showed beneficial effect in growth as well as essential oil.

It could be noticed that, the highest growth, yield and essential oil was obtained from mint plants grown under 100\% FC + DDM at $4 \mathrm{~g} / 10 \mathrm{~kg}$ soil which showed the least stress as the proline content recorded the lowest value $373.520 \mu \mathrm{g} / \mathrm{g}$ dry weight. Also, these plants produced essential oil with highest Carvone content $62.63 \%$ and D-Limonene of 25.37. This effect may be attributed to DMM application which promoted mint plant growth and mitigated stresses (Gong et al., 2005 and Tahir et al., 2006).

\section{Recommendation:}

It could be recommended to irrigating spearmint plants at $100 \%$ FC $+4 \mathrm{~g}$ $\mathrm{DDM} / 10 \mathrm{~kg}$ soil in order to obtain highest fresh and dry yield as well as the highest essential oil quantitatively and qualitatively.

\section{REFERENCES}

Abbaszadeh, B.; Sharifi Ashoorabadi, E.; Ardakani, M.R. and Aliabadi, F.H. (2008). Effect of drought stress on quantitative and qualitative of mint. Abstracts Book of $5^{\text {th }}$ International Crop Science Congress \& Exhibition, Korea, p. 23.

Abdalla, M.M. (2009). Sustainable effects of diatomite on the growth criteria and phytochemical contents of Vicia faba plants. $4^{\text {th }}$ Conference on Recent Technologies in Agriculture. November 2009, Fac. Agric., Cairo Univ., Giza, Egypt.

Abdalla, M.M. and El-Khoshiban, N.H. (2007). The influence of Water stress on growth, relative water content, photosynthetic pigments, some metabolic and hormonal contents of Triticium aestivum cultivars. Journal of Applied Sciences Research, 3(12):2062-2074.

Abdalla, Mona M. (2010). Sustainable effects of diatomite on the growth criteria and phytochemical contents of Vicia faba plants. Agric. Biol. J. N. Am., 1(5):10761089.

Abdalla, Mona M. (2011). Beneficial effects of diatomite on the growth, the biochemical contents and polymorphic DNA in Lupinus albus plants grown under water stress. Agric. Biol. J. N. Am., 2(2):207-220.

Abou-Dahab, T.A.M.; Harridy, I.M.A. and Mansour, B.A.B. (2010). Effect of irrigation and antitranspirant treatments on growth, yield and chemical constituents of marjoram plants (Majorana hortensis Moench). Bull. Fac. Agric., Cairo Univ., 61(3):274-285.

Afify, M.M.; Mazrou, M.M. and Eraki, M.A. (1993). The growth and essential oil content of Salvia officinalis L. plants as affected by watering intervals, nitrogen fertilization and their combinations. Zagazig J. Agric. Res., 20(6):1913-1924.

Aliabadi, F.H.; Valadabadi, S.A.R.; Daneshian, J. and Khalvati, M.A. (2009). Evaluation changing of essential oil of balm (Melissa officinalis L.) under water deficit stress conditions. J. Med. Plant. Res., 3(5):329-333.

Bates, L.S.; Waldren, R.P. and Teare, I.D. (1973). Rapid determination of free proline for water stress studies. Plant and Soil, 39:205-207.

Bichra, M.; El-Modafar, C.; El-Abbassi, A.; Bauamama, H. and Benkhalti, F. (2013). Antioxidant activities and phenolic profile of six Moroccan selected herbs. Journal of Microbiology, Biotechnology and Food Sciences, 2(4):2320-2338.

British Pharmacopeia (1963). Determination of Volatile Oil in Drugs. The Pharamaceutical Press London. 
Bunzen, J.N.; Guchard, J.; Labbe, P.; Sperinnet, P.J. and Trenchant, J. (1969). Practical Manual of Gas Chromatography. J. Trenchant Ed., ElSeiver Publ. Comp., Amsterdam, London.

Farahani, H.A.; Valadabadi, S.A.; Daneshian, J.; Shiranirad, A.H. and Khalvati, M.A. (2009). Medicinal and aromatic plants farming under drought conditions. Journal of Horticulture and Forestry, 1(6):68-92.

Faraz Ahmad, R.; Tariqu, A.; Mqusood, M.A.; Mukhram, A.T. and Shamsa, K. (2007). Effect of silicon application on wheat (Triticum aestivum L.) growth under water deficiency stress. Emir. J. Food Agric., 19(2):1-7.

Galvez, L.; Clark, R.B.; Gourley, L.M. and Maranville, J.W. (1987). Silicon interaction with manganese and aluminum toxicity in sorghum. J. Plant Nutr. 10:1139-1147.

Gong, H.J.; Zhu, X.Y.; Chen, K.M.; Wang, S.M. and Zhang, C.L. (2005). Silicon alleviaties oxidative damage of wheat plants in pots under drought. Plant Sci., 169(2):313-321.

Hattor, T., Inanaga, H. ;Araki, P. An; Mortia, S.; Luxova, M. and Lux, (2005). Application of silicon enhanced drought tolerance in sorghum biocolorPhysiologia Plant arum.(123):459-466.

Hoftman, E. (1967). Chromatography. Reinhold Pub. Corp., $2^{\text {nd }}$ Ed. p. 208-515.

Hou, L.; Eugeniusz, S. and Shangiun, X. (2006). Advances in Silicon research of horticultural crops. Vegetable Crops Res. Bullt., 64:5-17.

Hull, R.J. (2004). Scientists start to recognize silicon's beneficial effects. Golfdom, 60(8):69-72.

Jessen, L. (2007). Advertising sales business manager. Industry News, 1(250):629677.
Kruger, G. (2006). Certification decision Diatomite de Mozambique code 1959ZA0600R1educ. South Africa International, 1:3.

Laszlo, S. and Arnould, S. (2009). Proline: a multifunctional amino acid. Trends in Plant Science, 15(2):89-97.

Liang, Y.; Sun, W.; Zhu, Y. and Christie, P. (2007). Mechanisms of silicon-mediated alleviation of abiotic stress in higher plants: a review. Environmental pollution, 147(2):422-428.

Matichenkov, V.V. and Kosobrukhov, A.A. (2004). Si effect on the plant resistance to salt toxicity. $13^{\text {th }}$ International Soil Conservation Organization Conference Brisbane.

Mundree, S.G.; Bienyameen, B.; Shaheen, M.; Shaun, P.; Saberi, M.; Clare, V.W.; Kershini, G.; Alice, M.; Samson, M.; Jill, H.F. and Jennifer, A.T. (2002). Physiological and molecular insights into drought tolerance. African Journal of Biotechnology, 1(2):28-38.

Nan, R.; Carman, J.G. and Salisbury, F.B. (2002). Water stress, $\mathrm{CO}_{2}$ and photoperiod influence hormone levels in wheat. J. Plant Physiol., 159(3):307-312.

Penka, M. (1978). Influence of irrigation on the contents of effective substances in official plants. I International Symposium on Spices and Medicinal plants, Acta Hort., 73:181-198.

Poiata, A.; Hancianu, M.; Tuchilus, C.; Gill, E.; Gacea, O.; Aprotoaie, C. and Stanescu, U. (2006). Antibacterial activity of oil from Mentha viridis L. and Mentha piperita L. $4^{\text {th }}$ Conference on Medicinal and Aromatic Plants of SouthEast European Countries. $9^{\text {th }}$ National Symposium 'Medicinal Plants - Present and Perspectives'. $3^{\text {rd }}$ National Conference of Phytotherapy, Proceedings. Iasi, Romania, 28-31 May 2006, pp. 483-485.

Savant, N.K. and Sawant, A.S. (1995). Nutrient composition of rice seedlings as 
influenced by rice hull ash application to seedbed. Oryza, 43:62-71.

Savant, N.K.; Synder, G.H. and Datnoff, L.E. (1997). Silicon management and sustainable rice production. Advances in Agronomy, 58:151-199.

Snedecor, G.W. and Cochran, W.G. (1980). Statistical Methods. $6^{\text {th }}$ Ed. Iowa State Univ. Press, Ames, Iowa, USA., 507 p.

Tahir, M.A.; Rahmatullah, T.; Aziz, M.; Ashraf, S.; Kanwal, S. and Maqusood,
M. A. (2006). Beneficial effects of silicon in wheat (Triticum aestivum L.) under salinity stress. Pak. J. Bot., 38(5):715-1722.

Zhu, Z.; Wei, G.; Li, J.; Qian, Q. and Yu, J. (2004). Silicon alleviates salt stress and increases antioxidant enzyme activity in leaves of salt-stressed cucumber (Cucumis sativus L.). Plant Sci., 167:527533.

\section{التأثيرات الفسيولوجية للصخور الاياتومية على نباتات النعناع البلدي النامية تحت ظروف الجفاف لإنف}

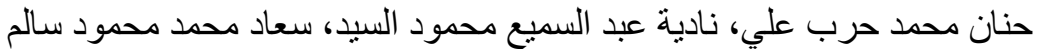

$$
\begin{aligned}
& \text { قسم بحوث النباتات الطبية و العطرية، معهد بحوث البساتين، مركز البحوث الزراعية، البعاد الجيزة، مصر. }
\end{aligned}
$$

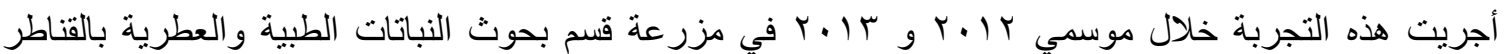

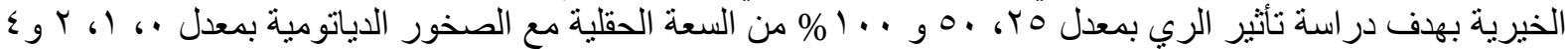

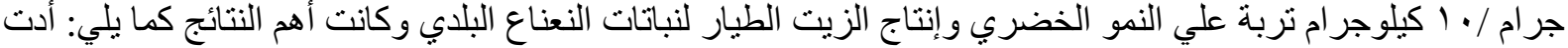

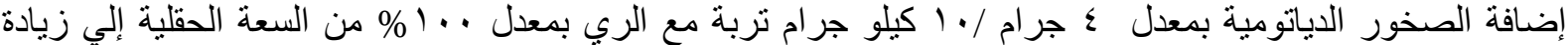

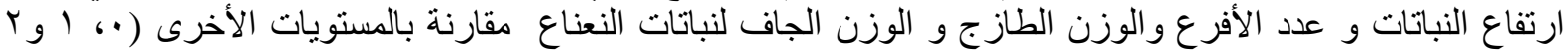

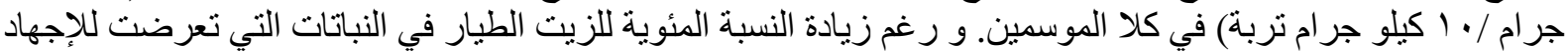

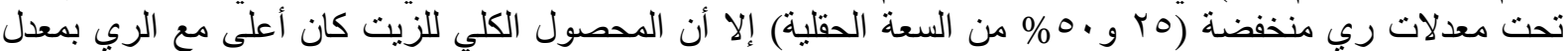

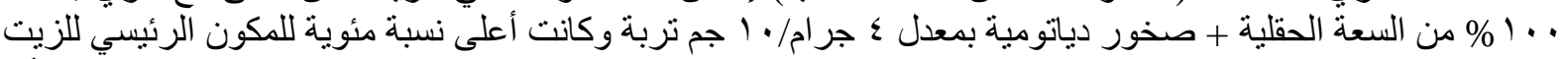
Carvone

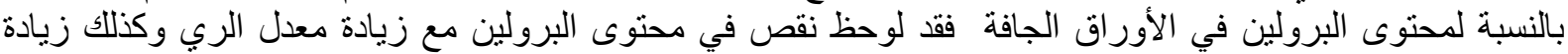

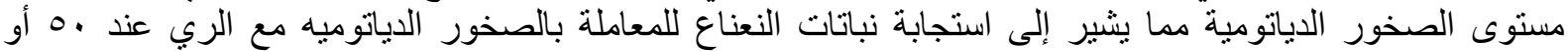

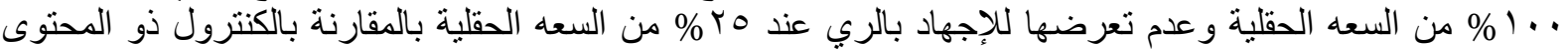

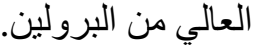


